\title{
Third Space of Legal Translation: Between Protean Meanings, Legal Cultures and Communication Stratification
}

\author{
Aleksandra Matulewska $^{1}$ (D) $\cdot$ Anne Wagner $^{2}$ (D)
}

Accepted: 21 October 2020 / Published online: 2 November 2020

(c) The Author(s) 2020

\begin{abstract}
Legal translation is a complex transfer of the text formulated in a source language into a target language which needs to take into account a wide array of factors to ensure the equality of parties to the process of interlingual communication. It is an autonomous realm of cross-cultural events within which the system-bound of legal concepts/notions deeply rooted in language, history and societal evolution of one country are transformed and integrated into the language of another, and as a result, stratified over the course of time (Mattila in Comparative legal linguistics, Routledge, Aldershot, 2006). That aspect of legal translation is called the Third Space (Bhabha in: Ashcroft B, Griffiths G, Tiffin H (eds) The post-colonial studies readers. Routledge New York, pp 206-209, 1995). The authors investigate some aspects of the Third Space including (1) Protean meanings and diverging legal cultures which are constantly remodeled, (2) cultural codes, and communication stereotypes as well as (3) communication problems stemming from stratification of communication in legal settings. The research methods applied include the semiotic analysis of legal translation strategies and potential loss of meaning.
\end{abstract}

Keywords Third space $\cdot$ Protean meaning $\cdot$ Legal translation $\cdot$ Stratification and translation $\cdot$ Cultural codes $\cdot$ Communication stereotypes

If the translator does his job as he should, he is a benefactor of humanity; otherwise he is a veritable public enemy. [49]

Without translation I would be limited to the borders of my own country. The translator is my most important ally. He introduces me to the world (Italo Calvino in [29])

Aleksandra Matulewska

aleksandra.matulewska@gmail.com

Anne Wagner

valwagnerfr@yahoo.com

1 Faculty of Modern Languages and Literatures, Adam Mickiewicz University, Collegium Novum, al. Niepodległości 4, Block A Room 107, 61-874 Poznan, Poland

2 ULR 4487 - CRDP - Centre de Recherche Droits Et Perspectives du Droit, University of Lille, 59000 Lille, France 


\section{Introduction}

Numerous scholars conducting research in legal translation turn attention to the socalled system bound or culture bound concepts and notions [6, 19, 46, 50, 51, 61], which exist in every natural language, including languages for specific purposes such as the language of the law. Languages are subject to culture [12, 30], comprising legal culture $[18,22]$, history and social changes that may be either evolutionary or revolutionary [32-36, 38, 39].

As such, legal translation is a space of possibilities, an autonomous realm of cross-cultural events within which the system-bound of legal concepts/notions deeply rooted in language, history and societal evolution of one country are transformed and integrated into the language of another, and as a result, stratified over the course of time [37]. Consequently, the initial space, the expected types of interactions, and the potential applications can extend the boundaries of these possibilities, and so lead to power dynamics in the process of interlingual communication serving the purpose of facilitating trade, exchange of ideas and ideologies, waging wars, espionage, cultural interplays and globalization. So, researchers in legal translation labor to gather terminology of multiple origins, to transfer it into another linguistic framework, and/or even to generate new knowledge. Furthermore, this framework is constituted of a binary code with two spaces: the source space and the target space. So, the legal translation process would then constitute the Third Space, a space-inbetween, "which enables other positions to emerge and where all forms of cultures are continually in a process of hybridity, of evolution" [48: p. 211]. Nonetheless, legal translation is not characterized by a quest of certainty but rather by an ongoing collectively accepted vision, meaning that variable phenomena can arise from one space to another, and so the legal translation process can be subject to appropriate notions/concepts/norms/standards, which are always local and limited in space. So, Third Space is undefined, vague, and fluid as a precondition for the negotiation, transformation, and translation between two cultures. Bhabha [3: p. 208] posits:

it is that Third Space, though unrepresentable in itself, which constitutes the discursive conditions of enunciation that ensure that the meaning and symbols of culture have no primordial unity or fixity; that even the same signs can be appropriated, translated, rehistoricized, and read anew.

The Third Space permits manipulation of the consciousness and unconsciousness of legal discourse when the translation process is underway, as it is a space of possibilities. So, "Cultural Mediation" [60] is an essential pillar within this space of possibilities, as it opens up a series of promising ways, alternatives, and compromises to create encounters and crossroads between disciplines for practical possibilities in the legal translation process. Therefore, the very nature of legal translation is to attempt to influence this space of possibilities. Such an attempt can only be achieved in a narrower space (Third Space) that legal translators aspire to use:

[It is a] Third Space of enunciation between the poles of cultural identity, a space within which cultural identities themselves are transformed [25, p. 120]. 
However, some scholars claim that translation is the art of impossible [44]. Others stress that "[Translation] may very probably be the most complex type of event yet produced in the evolution of the cosmos [...]" [47: p.250]. But there is no denying the fact that it is necessary, as George Steiner puts it "Without translation, we would be living in provinces bordering on silence" [53]. Therefore, it is an important task of legal translators and interpreters to combat inequality at various planes of communication [also cf. 1]. The imbalance of power between message senders and message recipients may lead to discrimination, miscarriage of justice and prejudice.

The aim of the paper is to focus on the multidimensional aspect of translation, being the Third Space of communication, frequently expected to be transparent, invisible like a windowpane though requiring complex analyses, since it is a complicated decision-making process impacted by time, protean circumstances and sublime factors. All this network of intertwined connections affects the translation process and its final product, i.e. the target text and its communication efficiency. From a theoretical perspective, the question may be posed which of the factors affecting the process of interlingual communication turned the translator into a cultural mediator [31], an interpreter [13] responsible for the successful transfer of meaning of the source text [16]. From a practical viewpoint, the debate is about how the translator determines the cultural, social and ideological identity of both the sender(s) of the source message and content and the message recipient(s) and his/her/their analyses in the target language.

The legal translation process itself is interdisciplinary in nature. It requires the knowledge of translation studies, efficient usage of translation skills encompassing the application of strategies, methods and techniques [15, 45, 50]. Apart from that, the translator in legal settings must be well versed in law and at least in one other domain. Finally, the translator needs to be a proficient user of the source and target languages that constitute the translation pair. Translators and interpreters not only need to know well the source and target languages but also the source and target cultures, the communication modes, the cultural codes, including stereotyping and mentality affecting processes of reasoning and analyses [60]. Furthermore, they are expected to have a proper psychological profile, which assumes that translators must be responsible, diligent, empathetic, impartial, objective and meticulous persons [16]. This blend of knowledge, personal features, skills and experience enabling the prediction of consequences, is amazingly multidimensional. Besides, it is a prerequisite for high quality legal translations and interpretations, which form a cross-cultural legal communication process [26, 59].

But there is no denying the fact that legal translation and interpretation aims are to provide efficient communication in legal settings to all communication process participants. Therefore, the task of intermediaries in this communication process (translators and interpreters) is to ensure the equality of expression and equality of understanding between the message senders and recipients. If one of the parties is deprived of the equal level of message comprehension, his/her rights may be discriminated against. 


\section{Protean Meanings and Legal Cultures}

Nations develop on a constant basis, socially, culturally, and technologically. At the same time as the nation building, the language development promotes the value in communication. The language users need to communicate about the changes they have brought but also the changes they intend to make. Similarly, the language of the law undergoes constant changes as it is said to be an evolving legal reality [17]. Despite the fact that laws are enacted in a manner ensuring their flexibility, i.e. using general terms that may be interpreted in the process of law enforcement in a manner consistent with the current state at which the society's development is progressing, terminology is impacted by several processes. Among the most important ones, we may enumerate:

1. partial change in the meaning of a term (as a result of broadening/narrowing down, or both broadening/narrowing down the meaning);

2. complete change of a term meaning (sometimes by providing a new definition of the term in use, or by using an already archaic sign);

3. archaization of the term and the abandonment of its usage;

4. coining new terms to denote new objects of reality or replace old terms considered politically or socially incorrect.

Such changes may lead to the occurrence of polysemous, partially equivalent or non-equivalent terminology in both synchronic and diachronic interpretation perspectives. So, translators need to follow the changes on a constant basis.

Let us provide an example illustrating the processes. The evolution of society, morals and the place of men and women in the couple has greatly contributed to changing the initial perception of the family. A couple no longer exists simply because there is a marriage between two opposite-sex persons. Indeed, at all levels, but in varying proportions and spatial-temporal frameworks, the traditional family model has led to a gradual evolution of the family unit. The parental couple is taking precedence over the marital couple (esp. in France). It is no longer a question of fulfilling one's conjugal duties, but of emphasizing the functions of parents in a conjugal regime [57, p. 8]. Today, couples who want to live together can choose three forms of conjugality (partnership, marriage and co-habitation) in France, the UK, Northern Ireland, thus making the family unit even more flexible. All those changes actually aim at amending for the imbalance of rights and obligations resulting from formal and informal family bonds.

In the UK legal system, under the Civil Partnership Act 2004, same-sex couples can register a civil partnership, having almost the same legal effects, rights and obligations as marriage for mixed-sex couples. But once the society got used to civil partnerships, a new wave of changes emerged:

The years 2013 and 2014 have brought a significant change in the meaning of terminology in that respect. The semantic changes have been introduced by the Marriage (Same Sex Couples) Act 2013 and the Marriage and 
Civil Partnership (Scotland) Act 2014. Those two acts in fact broadened the meaning of the term "marriage" to include "same-sex couples [38].

The Northern Ireland (Executive Formation etc.) Act 2019 came into effect on 13 January 2020, and so legalized same-sex civil marriage and opposite-sex civil partnerships in Northern Ireland, as provided in section of the Act 2019:

"In this section-

a. references to marriage in Northern Ireland (however expressed) include references to marriage outside of the United Kingdom by virtue of eligibility to marry in Northern Ireland (in accordance with Part 1 or Part 3 of Schedule 6 to the Marriage (Same Sex Couples) Act 2013);

b. references to forming a civil partnership in Northern Ireland include references to registering as civil partners outside the United Kingdom by virtue of eligibility to do so in Northern Ireland (in accordance with section 210(2)(b) or 211(2)(b) of the Civil Partnership Act 2004)."

In Scotland, same-sex marriage has been legal since 16 December 2014 with the enforcement of the Marriage and Civil Partnership (Scotland) Act 2014. Even the Law of the Church of Scotland allows ministers and deacons to marry opposite couples, ${ }^{1}$ which is not the case in France, for instance, where same-sex marriage is only a civil union.

In Poland, the term matzeństwo 'marriage' refers to a union of a man and a woman only, meaning that the British English term marriage (which means a union of two persons irrespective of their sexes) is no longer equivalent to the Polish term 'marriage'. It may be concluded here that if the text, which is to be translated from English to Polish, has been drafted after the Marriage (Same Sex Couples) Act 2013 entered into force, the Polish equivalent on some occasions will need to be supplemented with additional information that it is a marriage solemnized by persons of the same sexes or opposite sexes. But, when translating from Polish into English, one may need to highlight the fact that the Polish marriage is the institution which may be solemnized only by a man and a woman. What is more, medical findings provide us with a much more complex division of humans than the socially and traditionally ingrained one into males and females. We may also distinguish hermaphrodites. Doctors benefiting from genetic research distinguish several other sexes, that is to say the so-called biological karyotype sexes. The future will show how legal systems will react to medical findings and social changes, but there is no denying the fact that sex has been an important feature of a human being characteristics; e.g. it has been marked in passports to facilitate the identification of travelers in international transportation or to issue arrest warrants for criminals. From a legal perspective, the medical findings and advancements and the social transformations may be very problematic.

\footnotetext{
${ }^{1}$ https://www.churchofscotland.org.uk/_data/assets/pdf_file/0003/63930/marriage_and_civil_partn ership_scotland_act_2014_2020-update.pdf (retrieved on 16 July 2020).
} 
In France, the evolution of the marital couple with the law no. 2013-404 of 17 May 2013 opens marriage to same-sex couples. Under this Act, linguistic modifications appeared to make the feminine and masculine genders disappear by using terms that are said to be neutral. This neutrality in the French language is marked by the use of the masculine, the masculine in grammar prevailing over the feminine. Thus, "femme" has been replaced by "titulaire", "mari et femme" by "époux", "elles" by "ils", "père et mère" by "parents", "la femme assurée" by "l’assuré", "intéressée" by "assuré". This linguistic change is anything but a detail, since it opens the way to a change in the status of the family by making it more readable, reflecting the societal evolution within it.

Marriage has then to be interpreted in respect to specific territories and temporal frameworks. The richness of language and its adaptability to societal reality and medical advances will make it possible to show this pluralism, which is at the source of a shift in meaning from kinship to parenthood. Humboldt captured the nature of the evolution in language when he states that:

Language is not made up of isolated atoms, each of its elements announce themselves as merely part of a whole... the act of understanding required to conceive of the smallest term... is enough to grasp the whole of language [our translation] [24: p. 80].

\section{Cultural codes, Stereotypes, Communication Stereotypes}

Cultural codes [7] are unconscious images that are perceived when we communicate via verbal and non-verbal messages. They are ingrained in our brains as a result of upbringing, education and social interactions. In general, they are the effect of the environment in which we live and which we absorb day by day. If shared by many individuals, they form societal cultural codes and may be exploited for a variety of reasons, such as marketing campaigns, election campaigns, psychological manipulations, image shaping, etc. In translation studies, such signs are called culture-bound terms [50] or culturemes [43]. Their interpretations depend on a given communication community, either language community, territorial community or social community (social group).

When it comes to translation, we need to consider the so-called cross-cultural codes, because transfers in meaning have to take into account the transfer of the source language cultural code into the target language cultural code. Thus, the meaning modelled by cultural codes may be perceived as parts of subconsciously conveyed pragmatic meaning. Accordingly, cultural codes inevitably shape our perception of the surrounding world, also described with the Sapir-Whorf hypothesis [27]. The pragmatic load of meaning is extremely important, since it is perceived subconsciously by associations that affect the process of message interpretation.

Let us take the example of the term President. In most cases, the political system in which a given person lives affects the mode of perception of the term. The average core meaning, which is 'Head of the State', is understandable, though its pragmatic meanings may radically differ. Let us confirm our hypothesis by providing a 
few examples referring only to one feature of the presidential function, i.e. the age of candidacy in various countries. The age of candidacy in the Republic of Poland, that is to say the age at which a citizen can become a candidate running for the position of President, is 35 years. The same minimum age is required in Portugal, Ireland, Cyprus, and Austria. People below that age are considered not mature enough and not experienced enough to run for office. In France, ${ }^{2}$ Croatia, Finland, Kosovo and Turkey the age of candidacy for the presidential office is 18 years. At the same time in Germany, the Czech Republic, Estonia, Romania, the President should be at least 40 years old. In Italy, the President needs to be at least 50 years old. Here is shown the minimum age of candidacy in Europe. If we add to the equation other countries in other parts of the world, we may even find locations where there is no age limit, and where even minors can hold the office of President, as is the case in Israel. So aside from the age, there are additional connotations that should be taken into account when analyzing the process of transplanting [61] the term President from one language to another. They include the scope of power the President has in a given country. In some countries the function of the President is merely representative, as in Israel. In other countries the President has a wide scope of powers and can significantly influence the political and economic life of the country, it may even be very similar to a dictatorship (e.g. the cases of Presidents Suharto in Indonesia or François Duvalier in Haiti). In other countries, the power is divided and balanced between the Prime Minister and the President. There are many other issues that pragmatically mark the term President. In some countries a woman cannot run for office while in others the religious denomination is of substance and makes someone eligible or not (e.g. the President of Afghanistan must be a Muslim). Furthermore, there are linguistic issues in which only one term refers to the Head of the State, no matter whether he or she is the President, King, Emperor, Tsar, etc. The question arises here whether the term President in French, Polish, Italian etc. is similar in meaning, and may be treated as sufficiently equivalent or not. Definitely in a text devoted to the political system of a given country the age of candidacy will be an important aspect, which should be considered when translating the text. Even in newspaper articles devoted to presidential elections, the communication situation could impact the translation strategy.

If the person running for office is older-someone in his or her $40 \mathrm{~s}$ or $50 \mathrm{~s}$ - the explanations will not be needed. But if we translate from a language where the age of candidacy is 18 to the language where the age of candidacy is 35 or 50 and where the candidate running for office is in his or her $20 \mathrm{~s}$, then the readers should expect the translator to inform them that in the source language country the age of candidacy is radically different from their own cultural and legal reality [2]. Besides, we must take into account that for a person which has been brought up in a system where the age of candidacy is higher, it may absolutely be unacceptable to have a person considered immature elected. However, for a person brought up in the system where the age of maturity is 18 years old, it may be considered discriminatory and

\footnotetext{
${ }^{2}$ Before 2011, the minimum age in France was 23 years to run for presidential election.
} 
unequal, even prejudicial, not to be allowed to run for office. ${ }^{3}$ Accordingly, the legal living reality is under different spatial and temporal frameworks. So, even though the legal transplant [5] seems to be plain, a loss in meaning will prevail and may impact the whole picture from the source language. Indeed, numerous social factors affect the process of interlingual communication and message comprehension. Such differences unavoidably lead to the different reactions of source and target message recipients $[41,42]$. In such instances, the translation strategy must aim at reducing the communication distance between source and target language recipients.

Our last case would be to consider e-victimization and e-predation in communication strategies [58]. With new technological devices and social platforms, users can now introduce other supplementary visions of their mood. These social realities consist of funny little emojis, supposed to make the written conversation more animated. However, these cute emojis were quickly transformed, according to the moods and desires of their users, into dangerous icons advocating aggression from all directions, without any restrictions and any visibility of the opponent that the users had to face [55]. These so-called charming little signs turned into a real war of signs, a war of aggressiveness towards different interlocutors and/or communities, without being able to identify them immediately, because they were protecting themselves behind pseudonyms. This non-verbal communication proves to be much more difficult to transfer from the source language to the target language, as these small emojis can have radically different meanings, and sometimes even their users do not master the message as a whole. This war of nerves has led to numerous court cases, following SMS threatening messages, or SMS aiming at an intention of murder or incitement to suicide. Even judges sometimes find it difficult to decipher the message implied by these small signs, leaving an even greater opening for interpretation of the law. No doubt that the role of the translator will be even more complicated as these cool signs convey emotions and innuendoes. The problem gets even more difficult when a given, hermetic community uses an emoji as a symbol communicating a complex message such as some objects in the past. This is the case with sending a fish wrapped in a piece of clothing of some person, which was the old Sicilian mafia message informing about his or her death. The ability to decipher the message correctly in such instances requires an insider's knowledge.

\section{Stratification of Communication in Legal Settings}

The theory of social stratification is a well-known concept in sociological studies [10]. Since ages, societies have been divided into upper-class, middle-class, and lower class. There are various criteria to consider when dividing societies into various strata. One of the most frequently applied criteria is the economic one, that is

\footnotetext{
3 The issue of the sex of the person running of office is also interesting from that perspective. It turns out that law outpaces social prejudice. Though numerous countries give the right to run for office to both men and women, the election campaigns in which women decide to candidate show that numerous societies trust men more.
} 
to say the access to financial resources [9]. The access to financial resources was equal to the access to education, health system, food, culture, etc.[11, 21, 28]. Nowadays, the theory of stratification is also applied to nations. There is no denying the fact that stratification of societies and nations affects the process of communication, including communication in legal settings.

Right now, in many countries, the process of society stratification may be much more complex than in the past. The access to education is granted to wider public in developed countries as a result of nationwide strategies to combat illiteracy [28]. In such countries, systems of scholarship make it possible for gifted children from lower strata of society to acquire higher education, and to enable the country to take advantage of the intellectual potential of less affluent members of society. However, the belongingness to upper strata of society definitely facilitates access to various resources available on the market.

The question raised is whether the stratification of society actually affects the process of legal translation and interpretation. The answer to the question is affirmative, especially if we take into account that, in general, the purpose of legal translation and interpretation is to provide efficient communication in legal settings. From this perspective, we may distinguish several typical situations in which such communication takes place. The translators and interpreters are an intermediary link in the process of communication between message senders communicating in the source language and message recipients communicating in the target language. The members of these two groups frequently belong to different social strata in respect to education, gender, ethnic group, age, culture etc. All these aspects impact the communication process. Judges, lawyers representing their clients, professional translators and interpreters belong to the upper strata as far as education is concerned, as in the majority of instances they are graduates of universities who have acquired higher education. In terms of education parties to the proceedings such as claimants and defendants, victims, witnesses may belong to all types of social strata. Even if the addressees and recipients belong to the same educational stratum in terms of the educational level, some additional factors must be taken into account. Here are the possible situations.

1. addressees and recipients belong to the same educational stratum in terms of the educational level (e.g. graduated from schools of higher education);

2. addressees and recipients belong to different educational strata in terms of the educational level (addressees graduated from schools of higher education and recipients graduated from secondary level schools);

3. addressees and recipients belong to different educational strata in terms of the educational level (addressees graduated from schools of higher education and recipients graduated from primary level schools);

4. addressees and recipients belong to different educational strata in terms of the educational level (addressees graduated from schools of higher education and recipients are illiterate or almost illiterate)

5. addressees and recipients belong to different educational strata in terms of the educational level (addressees graduated from schools of secondary education and recipients graduated from schools of higher education); 
6. addressees and recipients belong to different educational strata in terms of the educational level (addressees graduated from primary schools and recipients graduated from schools of higher education);

7. addressees and recipients belong to different educational strata in terms of the educational level (addressees are illiterate or almost illiterate and recipients graduated from schools of higher education), etc.

Furthermore, we should know whether addressees and recipients belong to the same educational stratum not only in terms of the educational level (e.g. graduated from schools of higher education), but also in terms of their educational profile, which may be heterogeneous (they acquired education in different disciplines) or homogeneous (they acquired education in the same discipline).

When communicating in the native language, we usually resort to communication means adjusted to the educational, age, gender, and social status profiles of our interlocutors. As it turns out, when communicating in a foreign language, it is much more difficult to consider these factors, since translation is based on consciousness and not on intuition. Therefore, the task of the translators and interpreters is to adjust the message in linguistic terms (style, sophistication of grammatical structures, sophistication of terminology) to the profile of interlocutors if the risk occurs that they may not be able to understand the message properly.

At the age of globalization apart from the above-mentioned strata, we also need to take into account the already mentioned nation stratification. In general, when talking about countries at present they are divided into core countries, semi-periphery countries and periphery countries [4, 23]. The core countries are well-developed countries having at their disposal vast economic resources, access to advanced technologies and production processes. The inhabitants of core countries enjoy a relatively comfortable lives with education access, no matter to which social strata of the society they belong. The opposite pole are periphery countries which are slowly developing countries, having no significant economic resources, the economy of which is based mostly on cheap physical workforce. In such countries, there are high illiteracy rates, people frequently suffer from malnutrition, the access to the health system is significantly limited and many people die of disease that may be curable or have been eradicated in other countries. The semi-periphery countries may be compared to the middle classes of society. It means that they are much more advanced and can provide their citizens with much better living conditions than periphery countries, but they have fewer economic resources than the core countries. As stratification of nations and translation are concerned, we need to solve communication problems occurring in the Third Space. The languages of core countries are welldeveloped, especially in terms of languages for specific purposes. It is a direct result of the need to communicate precisely in various settings, including legal settings. The inhabitants of periphery countries, due to the deficiency of the access to technology, numerous resources, education, communicate in a much simpler language, some languages for specific purposes are not used at all in such countries, and the level of understanding of certain processes, reality, concepts is consequently limited.

The translation from a periphery nation language into the semi-periphery or core nation language does not pose difficulty as far as the process of translation or 
interpretation is concerned. However, it may be difficult for the recipients of the target text to understand the mentality and the difference in a comprehension level of the interlocutor.

The translation from core or semi-periphery languages into the periphery languages may be extremely difficult for the translator or interpreter. It is due to the fact that the target language may not have signs denoting specific objects, concepts of source language reality. Yet, each language has word formation potential, but this potential may be extremely difficult to overcome, should we consider not only the need to coin new signs or to provide a circumvent equivalent, but also the need to broaden the knowledge of the message recipient by educating him or her to make the sign meaningful and properly decodable.

Additionally, when discussing the Third Space in translation and interpretation, we also need to consider the language acceptability in a given communication situation. By using words having the same referential meaning but inappropriate pragmatic meanings, we may evoke improper emotions such as disdain, aggression, humiliation and offence. Sometimes it is the political correctness which enforces the change in the lexicon. Let us quote Garner who points out the reasons for terminology differentiation in law:

Many legal euphemisms originated in a Victorian sensibility. Our digests of the law, for example, include sections under the phrase disorderly houses because writers considered whorehouses or brothels or bordellos too indelicate. (The non-legal euphemism is house of ill fame or repute ). Despite its appearance, criminal conversation is not a legal doctrine that runs afoul of the First Amendment; the phrase refers to adulterous sex (which, of course, inevitably interferes with conjugal felicity ). Only recently have we sloughed off the overzealous euphemizing about homosexuality, known formerly as the abominable and detestable crime against nature. Although some euphemisms, like the last one, are terribly slanted, others result from an understandable desire to sound objective, by avoiding biased words of the past. Extramarital, for example, strikes us as more neutral than adulterous (as used in the previous paragraph). And many legal writers are now inclined to use non-marital children or children out of wedlock instead of illegitimate children or, worse yet, bastards . Why indeed scar the innocent children with ugly epithets. [14: p. 34]

In some social strata the term bastard will be used, whereas in others it will be unacceptable and politically incorrect.

This Third Space in translation and interpretation processes, which is affected by social and nation stratification, is frequently neglected in translation studies. Some scholars even claim that it is not the task of the translator or interpreter in legal settings to bother about making sure that the recipient correctly understands the message. However, if we take into account that legal translations and interpretations are a pillar safeguarding the observance of human rights in a situation when people cannot communicate in their native language with the apparatus of judiciary in a broad sense, we need to assume that the only possibility to observe human rights in this respect is to provide efficient communication in legal settings, which means that the 
recipients of messages understand them properly and are able to react to them in a manner which safeguards their human rights ${ }^{4}$.

We should stress here the problem of communication process inequality. A foreigner who must communicate in legal settings in a country of unknown legal system will inevitably misunderstand the source language message due to his or her interpretation through the prism of the legal system he or she knows best. Though the referential meaning may be successfully conveyed by the translator, the pragmatic meaning is much more difficult to carry. So, the issue of communication process inequality should be deeply investigated. Very frequently, communication in legal settings and its effectiveness is based on the sublime arrière-pensée, overtones and message nuances which may disappear in the process of translation or interpretation. It may result in a situation when one interlocuter understands and communicates precisely, whereas the other does not and gets no help.

There is also the problem of the imbalance of power in the process of communication in legal settings, already described above, which encompasses the communication between the upper and lower/inferior classes of society, as well as the upperclass nations and lower-class nations. Analogously, we should remember about high and low context cultures:

communication cultures and rules of cultural communication differ in various countries considerably. These phenomena are well-known in linguistic studies and described as high context cultures and low context cultures. People coming from low context cultures will be open to take active part in communication and will be prone to ask questions and find answers when they do not understand the message fully. However, people from high context cultures where asking questions is considered either rude or inappropriate (e. g. due to the social hierarchy that must be obeyed in the process of communication) will behave differently. There are also cultures in which asking questions equals to admitting one's insufficient knowledge in a given field, and therefore in order not to lose one's face such persons are going to pretend they understand the message. [40 ]

\footnotetext{
${ }^{4}$ [8] The Convention for the Protection of Human Rights and Fundamental Freedoms signed in Rome on 4 November 1950. That convention provides in article 5 that: "2. Everyone who is arrested shall be informed promptly, in a language which he understands, of the reasons for his arrest and of any charge against him.".

${ }^{5}$ One cannot ignore the existence of the so-called community interpreters in legal settings. The existence is enforced by the need to communicate interlingual in a situation when no professional interpreter is available for a given pair of languages. Such interpretation requires a separate article when the complexity of the process and the multi-dimensionality of factors intervening in the process of translation and interpretation exceed the scope of this paper. Let us simply say here that community interpreting is the necessary evil, which enables to communicate without guaranteeing the efficiency of communication in a situation where otherwise there would be no communication at all.
} 


\section{Concluding Remarks}

The Third Space in translation is multi-dimensional and extremely complex due to the factors mentioned above. The task of the translator is to make the speaker visible to those who do not understand the language he or she uses. As Bhabha ([3], p. 47) claims message senders must stop being invisible, they must be seen, heard and understood to avoid political alienation and cultural discrimination (Bhabha [3], p. 60). The otherness must not only sub-exist but it must be tolerated and accepted as a partner in communication process. The more distant the source and target language cultures are (in respect to a wide array of social, economic, legal, historical, political, racial, linguistic factors), the longer the chain of translation (number of pivot languages between the source language of the message sender and the target native language of the message recipient), the more difficult it is to communicate efficiently. Our paper shows how language is powerful and active, conveying social experiences and shaping the reality of legal translation both in theory and in practice. It is noteworthy that practitioners and experts in this fields are sensitive to an "assumed translation" [54], where legal translation could accommodate both the source and target languages:

Assumed translation would be regarded as any target-culture text for which there are reasons to tentatively posit the existence of another text, in another culture and language, from which it was presumably derived by transfer operations and to which it is now tied by certain relationships [...] within that culture [ 54 : p. 29].

For this reason, legal translators and interpreters make decisions and choices that reflect common knowledge, but they still operate within the constraints set by the principle of the cultural reality in the target language:

Semiotically speaking, it will be clear that it is the target or recipient culture, or certain section of it, which serves as the initiator of the decision to translator and of the translating process [...] Translators operate first and foremost in the interest of the culture into which they are translating, and not in the interest of the source text, let alone the source culture [ $52:$ p. 49]

To sum up, the Third Space of translation is really important in the combat for ensuring equal rights to message senders and recipients. The diversity of communication circumstances, the varied needs of communication participants, the diverging legal systems, social conventions and moral standards $[20,56]$ make the process of translation burdened with the Third Space. Furthermore, the signs we use evolve constantly as a result of social, economic, political, technological and other types of changes to which societies are susceptible. Nevertheless, though not always perfect or satisfactory, translation and interpretation is necessary to communicate in the age of globalization.

Finally, translators and interpreters are supposed to be specialists in interlingual communication and mediators between cultures, mentalities and social barriers. It is their task to make participants to the process of interlingua communication aware of 
nuances that may hinder mutual understanding, that may lead to opaque interpretations of messages. They are the guardians of human right observance in interlingual communication when the comprehension of messages sent and received is of vital importance to the communication process participants. The foreigner, requiring the assistance of the translator or interpreter, always constitutes a minority that may be underrepresented unless proper linguistic help is provided to them. Additionally, their visual otherness can make the majority prejudicial against them. If their rights are to be observed and they are to have equal standing, the intermediary in linguistic communication must make them fully comprehended. At the same time, if the interpreter or translator censors the message uttered by the 'minority' member, the rights of the 'communication majority' may be infringed, even due to the interpreter's polished and censored target version of the original message. A witness, who is a foreigner, in legal proceedings may become more trustworthy than a witness, who speaks the language of the court. The process of legal translation is very susceptible to the Third Space as metaphorically described by Bhabha [3], and may be subject to a wide array of manipulations.

Open Access This article is licensed under a Creative Commons Attribution 4.0 International License, which permits use, sharing, adaptation, distribution and reproduction in any medium or format, as long as you give appropriate credit to the original author(s) and the source, provide a link to the Creative Commons licence, and indicate if changes were made. The images or other third party material in this article are included in the article's Creative Commons licence, unless indicated otherwise in a credit line to the material. If material is not included in the article's Creative Commons licence and your intended use is not permitted by statutory regulation or exceeds the permitted use, you will need to obtain permission directly from the copyright holder. To view a copy of this licence, visit http://creativecommons.org/licen ses/by/4.0/.

\section{References.}

1. Bender-Säbelkampf, Theresa. 2019. Austria's going backwards on gender equality. In Legal dialog. Topics from civil society. https://legal-dialogue.org/austrias-going-backwards-on-gender-equality Accessed on 10th June 2020.

2. Berger, P.L., and T. Luckmann. 1991. The social construction of reality: A Treatise in the sociology of knowledge. London: Penguin.

3. Bhabha, Homi K. 1995. Cultural diversity and cultural differences. In The post-colonial studies readers, ed. B. Ashcroft, G. Griffiths, and H. Tiffin, 206-209. New York: Routledge.

4. Bordo, Michael D. and Marc Flandreau. 2001. Core, periphery, exchange rate regimes, and globalization. NBER working paper no. 8584.

5. Cairns, John W. 2013. Alan watson, and the history of legal transplants. Georgia Journal of international Law and Comparative Law. 41: 637-687.

6. Cao, Deborah. 2007. Translating law. Clevendon: Multilingual Matters LTD.

7. Clotaire R. 2006. The culture code: An ingenious way to understand why people around the world live and buy as they do. New York. ISBN 978-0-7679-2056-8.

8. Convention for the Protection of Human Rights and Fundamental Freedoms Rome, 4 November 1950.

9. Dahrendorf, Ralf. 1959. Class and class conflict in industrial society. Stanford, CA: Stanford University Press.

10. Davis, Kingsley, and Wilbert E. Moore. 1945. Some principles of stratification. American Sociological Review 10(2): 242-249. JSTOR, www.jstor.org/stable/2085643. Accessed 14 July 2020. 
11. De Graaf, P., H.B.G. Ganzeboom, and M. Kalmijn. 1989. Cultural and economic dimensions of occupational status. In Similar or different? Continuities in dutch research on social stratification and social mobility, ed. W. Jansen, J. Dronkers, and K. Verrips, 53-74. Amsterdam: SISWO.

12. Engberg, Jan, and Kirsten Wølch Rasmussen, eds. 2010. Cognition, meaning making, and legal communication. Special issue of The International Journal for the Semiotics of Law 23/4.

13. Gadamer, Hans-Georg. 2016. Hermeneutics between history and philosophy: The selected writings of hans-georg. Gadamer. Pol Vandevelde and ArunIyer, London: Bloomsbury.

14. Garner, Brian A. 2002. The elements of legal style. Oxford: Oxford University Press.

15. Gémar, Jean-Claude., and Nicholas Kasirer. 2005. Jurilinguistics: Between law and language. Montreal: Thémis.

16. Gémar, Jean-Claude. 2000. Traduireoul'artd'interpréter : Langue, Droit et Société : Éléments de jurilinguistiques, Tomes 1 \& 2. Québec: Presses de 1'Université du Québec.

17. Gény, François. 1922. Sciences et Techniques en Droit Privé Positif. Tome 1. Paris: Recueil Sirey.

18. Goddard, Ch. 2009. Where Legal Cultures Meet: Translating Confrontation into Coexistence. InvestigationesLinguisticae 17: 168-205.

19. Goodrich, Peter. 1990. Languages of law: From logics of memory to nomadic masks. London: Weidenfeld and Nicolson.

20. Hale, Matthew. 1966/1765. History of the pleas of the crown, vol.1. London: Dawsons.

21. Hauser, R.M., and D.L. Featherman. 1977. The process of stratification: trends and analyses. New York: Academic Press.

22. Herrera, Carlos Miguel. 2016. Special issue "Legal Culture in Political Perspective". International Journal for the Semiotics of Law 29(4): 721-727.

23. Hryniewicz, Janusz. 2014. Core-periphery-an old theory in new times. European Political Science 13: 235-250. https://doi.org/10.1057/eps.2014.5.

24. Humboldt, von W. . 1974. Introduction à l'œuvresur le Kavietautresessais. Paris: Seuil.

25. Ikas, Karin, and Gerhard Wagner (eds.). 2009. Communicating in the third space. London: Routledge.

26. Jopek-Bosiacka, A. 2010. Legal communication: A cross-cultural perspective. Warsaw: Warsaw University Press.

27. Kay, Paul, and Willet Kempton. 1984. What is the Sapir-Whorf hypothesis? American Anthropologist 86 (1): 65-79. https://doi.org/10.1525/aa.1984.86.1.02a00050.

28. Lenski, Gerhard. 1984. Power and privilege. A theory of social stratification. Chapel Hill, London: The University of North Carolina Press.

29. MacShane, Frank. 1983. The fantasy world of Italo Calvino. New York Times. National edition. July 10, 1983, Section 6, Page 23. https://www.nytimes.com/1983/07/10/magazine/the-fantasyworld-of-italo-calvino.html Accessed on 10th June 2020.

30. Malinowski, B. 1961. A scientific theory of culture and other essays. New York: Oxford University Press.

31. Malmkjær, K., K. Windle, and S. Bassnett. 2011. The translator as cross-cultural mediator. In The Oxford Handbook of Translation Studies. Oxford: Oxford University Press. Retrieved from 14 July 2020, https://doi.org/10.1093/oxfordhb/9780199239306.001.0001/oxfordhb-9780199239306-e-008, https://www.oxfordhandbooks.com/view/. Accessed on 10th June 2020.

32. Mańko, R. 2014. 'Koncepcjainterpelacjiideologicznej a krytycznydyskurs o prawie' [The Notion of Ideological Interpellation and Critical Discourse on Law]. ArchiwumFilozofiiPrawaiFilozofiiSpotecz nej 8: 41-54.

33. Mańko, R. 2015. 'Legal survivals: A conceptual tool for analysing posttransformation continuity of legal culture. In Tiesıbuefektivitatepostmodernasabiedrıba, ed. J. Rozenfelds, 16-27. Riga: Latvia University Press.

34. Mańko, R. 2015. Reality is for those who cannot sustain the dream: Fantasies of selfhood in legal texts. Wroctaw Review of Law, Administration and Economics 5 (1): 24-47.

35. Mańko, R. 2016. Wybranereliktyprawneepokisocjalizmurealnego w polskimprawiecywilnym analizazmianyfunkcjispołecznejinstytucjiprawnychwnastępstwietransformacjiustrojowej [Selected legal survivals of the period of actually existing socialism in polish civil law: An analysis of the change of social function of legal institutions as a consequence of systemic transformation]. Studialuridica 66: 207-235.

36. Mańko, R. 2016. 'Demons of the past? Legal survivals of the socialist legal tradition in contemporary polish private law. In Law and critique in central Europe: Questioning the past, resisting the present, ed. R. Mańko, C. Cercel, and A. Sulikowski, 66-89. Oxford: Counterpress. 
37. Mattila, Heikki E.S.. 2006. Comparative legal linguistics. Aldershot: Routledge.

38. Matulewska, A. 2017. Socially induced changes in legal terminology. Studies in Logic, Grammar and Rhetoric 49 (1): 153-173. https://doi.org/10.1515/slgr-2017-0010.

39. Matulewska, A. 2018. Legal languages-A diachronic perspective. Studies in Logic, Grammar and Rhetoric, 43 (66): 195-212. https://doi.org/10.2478/slgr-2018-0011.

40. Matulewska, Aleksandra. 2017. Communities of message senders and recipients in legal settings and their communicative needs. The translator's perspective, International Journal of Legal Discourse 2 (1): 29-46. https://doi.org/10.1515/ijld-2017-0001.

41. Nida, Eugene. 1964. Toward a science of translating. With special reference to principles and procedures involved in bible translating. Leiden: Brill.

42. Nida, Eugene, and Charles R. Taber. 1982. The theory and practice of translation. Leiden: E. J. Brill.

43. Nord, Christiane. 1997. Translating as a purposeful activity. Manchester: St Jerome.

44. Ortega y, Gasset, and Elizabeth Gamble Miller. 1992. The misery and the splendor of translation. In Theories of translation: An anthology of essays from Dryden to Derrida, ed. Rain Schulte and John Biguenet, 93-112. Chicago: University of Chicago Press.

45. Ramos, Fernando Prieto. 2011. Developing legal translation competence an integrative process-oriented approach. Comparative Legilinguistics-International Journal for Legal Communication. 5: 7-21. https://doi.org/10.14746/cl.2011.5.01.

46. Rayar, L. 1992. Translating law: Method or madness? In International forum of legal translation 1992 proceedings, ed. J. Miller, 62-71. Warszawa: Wydawnictwo TEPIS.

47. Richards, Ivor A. 1953. Toward a theory of translating. In Studies in Chinese thought, ed. Arthur F. Wright, 247-262. Chicago: University of Chicago Press.

48. Rutherford, John. 1990. The third space: Interview with HomiBhabha. Identity, community, culture, difference. London: Lawrence \& Wishart.

49. Saenz Miguel. 2016. Revista CTPCBA (Colegio de Traductores Públicos de la Ciudad de Buenos Aires) No. 131 Published on September 1, 2016, 9. https://issuu.com/revistatrad/docs/revistactp cba131web. Accessed on 10th June 2020.

50. Šarčević, S. 2000. New approach to legal translation. The Hague: Kluwer Law International.

51. Šarčević, Susan. 1985. Translation of culture-bound terms in law. Multilingua 4 (3): 127-133.

52. Snell-Hornby, Mary. 1988. Translation studies: An integrated approach. New York: Benjamins Publishing.

53. Steiner, George. 1967. Language and silence. Essays on language literature and the inhuman. New York: Atheneum.

54. Toury, Gideon. 1995. Descriptive translation studies and beyond. New York: Benjamins.

55. Wagner, Anne, Marusek Sarah, and Yu Wei (eds). 2020. Special issue. Getting far too emotional with emojis: The digital influencers in E-discourse aggressiveness. In Social semiotics, vol. 30/3.

56. Wagner, Anne. 2016. Multiple historical and social layers of interpretation of marital rape in England. Semiotica 209: 43-58.

57. Wagner, Anne. 2018. Le champ familial: unevoie de reconstruction entre pouvoir, résistance et mutation. In De la procréationmédicalementassistéeélargie à la procréationaméliorée: versl'ébranlement de certainsinterdits, ed. Bérengère. Legros, 317-332. Paris: LEH Édition.

58. Wagner, Anne. 2019. E-victimization and E-predation theory as the dominant aggressive communication: The case of cyber bullying. Social Semiotics 29 (3): 303-318.

59. Wagner, Anne and Gémar, Jean-Claude (eds). 2013. The process of translatabiliting: Translating and transferring law, its concepts, notions and language. Special Issue of the International Journal for the Semiotics of Law 26/4.

60. Wagner, Anne, and Gémar, Jean-Claude (eds). 2015. Legal translation and Jurilinguistics: Globalizing disciplines. Retrospects and prospects. Special issue of the International Journal for the Semiotics of Law 28/1.

61. Watson, A. 1993. Legal transplants: An approach to comparative law. Athens, London: University of Georgia Press.

Publisher's Note Springer Nature remains neutral with regard to jurisdictional claims in published maps and institutional affiliations. 